\title{
NON-FORMAL EDUCATION WITHIN THE FUNCTION OF RESPONSIBLE PARENTING
}

\author{
Dr. Dragana Bogavac, University of Belgrade, Teacher Training Faculty, Belgrade, Serbia \\ E-mail: dragana.bogavac@uf.bg.ac.rs \\ Dr. Tatjana Milosavljević Đukić, University of Nis, Pedagogical Faculty, Vranje, Serbia \\ E-mail: tatjanamdj@ucfak.ni.ac.rs
}

\section{AR T I C LE INFO}

Original Research

Received: May, 18.2017.

Revised: June, 01.2017.

Accepted: Jun, 06.2017.

doi:10.5937/IJCRSEE1701031B

UDK

37.018 .48

\section{Keywords:}

non-formal education,

parents,

responsible parenting.

\begin{abstract}
A B S T R A C T
The aim of this survey was to discover to what degree parental nonformal education is present within the function of responsible parenting. The questionnaire research method was used in the survey. For the purpose of this research a questionnaire of 13 questions was constructed relating to the forms of non-formal education, and another questionnaire of 10 questions relating to the parents' expectations of non-formal education. The sample included 198 parents. Examination of the scores concerning the presence of certain forms of parental non-formal education realized in cooperation with the school leads to the conclusion that the parents possess a positive attitude towards non-formal education. The analysis showed that the parents' expectations were not on a satisfactory level. According to the results, the fathers displayed a greater interest towards non-formal education $(7.72 \pm 1.35)$ than the mothers $(6.93 \pm 1.85),(\mathrm{p}<0.05)$. Unemployed parents had a greater score $(7.85 \pm 1.30)$ than the employed parents $(7.22 \pm 1.71),(\mathrm{p}<0.05)$. A difference in the acceptance of non-formal education in accordance with the level of formal education was also noticeable $(\mathrm{p}<0.001)$. Respondents with a high school degree displayed the highest level of acceptance (7.97 \pm 0.78 ), while the lowest interest was seen in respondents with an associate degree $(6.41 \pm 2.29)$. Univariate linear regression analysis showed that statistically important predictors were: gender (OR: $-0.23(-1.24--0.33), \mathrm{p}<0.001)$, work status (OR: $-0.14(-1.24--0.01),<0.05)$ and the level of formal education (OR: $-0.33(-0.81--0.34), \mathrm{p}<0.001)$. The final results lead to the conclusion that parental non-formal education supports the concept of lifelong education.
\end{abstract}

(C) 2017 IJCRSEE. All rights reserved.

\section{INTRODUCTION}

A child's life begins with the family where certain relations have already been established by the parents taking up the role of educators. Therefore, a corpus of activities which represent certain elements of parenting can be recognized in the process of family upbringing. In the last couple of years special attention has been paid to the key elements of parenting. Therefore »one should start from

\section{Corresponding Author}

Dr. Tatjana Milosavljević Đukić, University of Nis, Pedagogical Faculty, Vranje, Serbia

E-mail: tatjanamdj@ucfak.ni.ac.rs

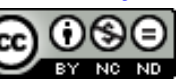

This work is licensed under a Creative Commons Attribution - NonCommercial - NoDerivs 4.0. The article is published with Open Access at www.ijcrsee.com the assumption that a person's abilities for the role of a spouse, as well as one's skills for the role of a parent is not an exclusive right of any social class, nor is it in direct link with the cultural level of the concerning sides« (Pati, L., 1999, 163).

A child's education had been the parents' responsibility in every historical epoch. However, the manner in which educational function was applied by the parents had been changing in the way aims which the parents laid down for themselves were changing, in the way educational attitudes were changing as well as parental educational styles. Family educational perspective must be focused towards the activation of existing family resources where the parents are competent to independently establish a parental style whose characteristics are $\gg$ conceptualized rationalities: the aim is to support an integrated as well as integrating perspective which includes co- 
ordination and establishment of disciplinary knowledge that in turn would affect different dimensions of the family altogether as well as the multitude of dimensions of the problem. It is a perspective that takes into account the context of family life, not only life inside the family circle, a perspective which establishes implicit educational theories which every family risks implementing in order to clarify them and make them evident, a perception which would function in a contemplative environment and ambiance of established rationality, constantly searching for something which may be called »invisible knowledge« with the aim of improving the processes that focus on the intent of conscious action and not only on automatic action « (Milani, 2002, 19). Specifically, parents should realize that it is important to understand and experience child education within a family as an essential experience that incorporates a personal character and certain social discourses. Therefore, it includes »assisted normality which essentially means to educate, to educate in the style of mutual knowledge exchange, trust, cooperation and various efforts against the transfer of one's own responsibilities on others, it means establishing unified action plans against the all-powerful ways of the institution which acts on its own, it means action within the circle of partnership logic, within the context of intersubjectivity with the aim of making people aware of the importance of accountability of various actors, which enables, above all, the way of improvement and independence of the family« (Milani, 2002, 20).

It is necessary to point out that the parents' education $»$ is different from other forms of action in the sense that it is addressed to the public without exceptions. It relates to all the answers, activities, abilities that are even in the slightest relation to education. Also, it's intention differs from other approaches: it doesn't aim to achieve an explicit behavioral change or some already defined and existing structures, but it tries to expend the competencies and educational abilities of all the members of the community « (Pourtois, Forgione, Desmet, 1989, 265). Therefore, in order for it to be an essential support for parents, it is important for it to »happen on account of the parental pair's resources, and in this way their parental capacity is growing. Because of it, parental education for the educational role represents the means for strengthening the family's individuality and abilities and supporting them, acknowledging present resources within the family nucleus« (Simeone, 2012, 175).
Programs dealing with parental education for the process of parenting are intended to provide parental assistance in order to ease their insecurity with their parental role and therefore contribute to the creation of healthy relationships between parents and children.

Parental education programs have to be based on a thorough analyses of a family as a system and also of the social context, because »entering into someone else's life, home, in his everyday routines, family relationships, and therefore, often into the interior of one's unpleasant and painful experience, demands a great ability of mobility regulation, words, silence, presence and absence, but also that regulation can often contain within itself a dose of suffering and assistance in the developing phase « (Janssen, 2005, 9).

Knowledge and education represent strategic development factors of society. Education in general, especially non-formal education is in a serious crisis and in stagnation in our country.

General expansion of non-formal education and its successful connection with formal and permanent education represents a new kind of development quality of overall pedagogical theory and practice. Therefore, permanent education is becoming a strategic development factor of every society. Its basic objective is to explore the most effective ways, methods and forms of acquiring knowledge from birth until the end of human life.

Formal, non-formal and informal education present a unique, complex process (Figure 1).

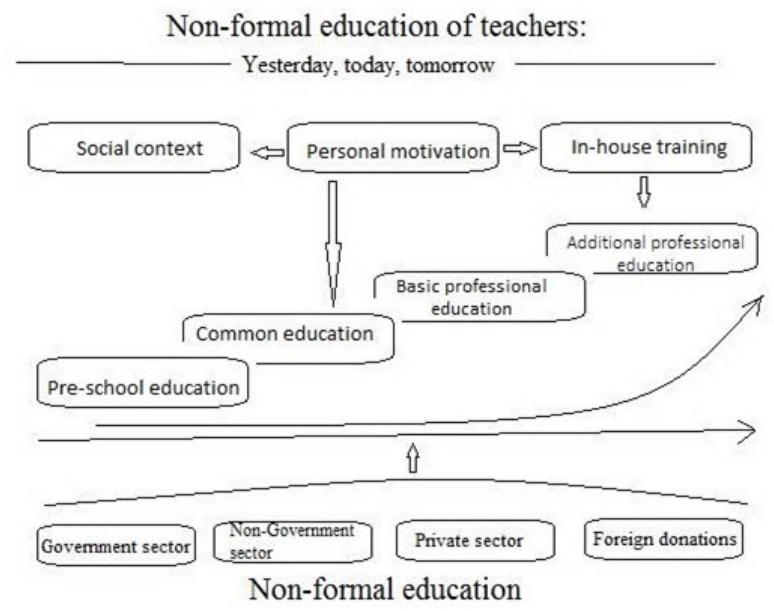

Figure 1. Non-formal education as a segment of lifelong education

Therefore, lifelong education comprises of segments which complement each other. Thus, inclusion of an individual into various phases of education is possible (Protasevich, 
2011, 75-76). An individual can during his lifetime create his own educational path which depends on the social context (Повседневный социум) and personal motivation (Личная мотивация). With the aim of improving knowledge, skills and abilities, non-formal education represents a part of the educational system which can be organized by the government (Государственный), non-government sector (Негосударственный), private sector (Частный) and from foreign donations (Зарубежные провайдеры).

It is important to point out the components of non-formal education (Figure 2). The components of non-formal education are: communication (Общение), the subject of communication (Предмет общения), motives of communication (Коммуникативные мотивы), communicational action (Действия общения), the need for communication (Потребность в общении), communicational tasks (Задачи общения), communicational means (Средства общения), products of communication (Продукты общения) and the aim of communication (Цель).

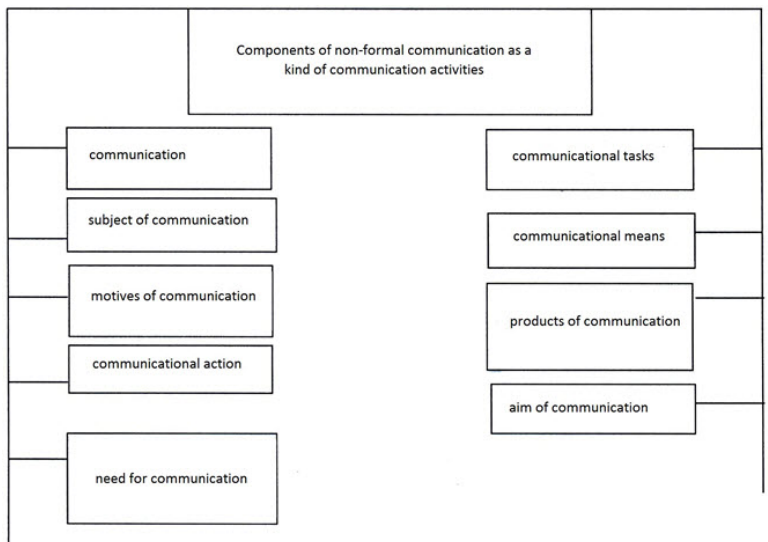

Figure 2. Components of non-formal communication

The above mentioned components can be understood as a way of communicative action. Depending on the organization of nonformal education there exist three types of communication: macro level communication (communication doesn't appear as an activity but as a form of interaction between people involved in various activities in a social context), mezo level communication (professional contacts), and micro level communication (the basic unit of communication) (Lomov, B. F., 1979, 34-47).

Refining one's own personality is a primary objective of every individual. The increasing complexity of modern family structure as well as the ever growing respon- sibilities it implies, demands a certain level of education and self-education. A well-known fact of the present is that systematic preparation for family life is rather neglected. In this regard, everything that has been neglected in the institutional education system needs to be achieved and compensated by means of selfeducation. Complete knowledge of family and family interactions, elasticity in family relations toward its members and creativity in the process of establishing a positive family atmosphere are important aims of this type of self-education.

Adult education as a preparation for responsible parenting should begin during regular education of young people. It should constantly be updated with certain contents depending on the age and needs.

Within the field of child education, parents go to great lengths led by wishes, intentions and endless effort. However, successes are not always complete, noble wishes are not fulfilled and parents' efforts are met with the latest challenges of educational action. The results of children's family upbringing are dependent upon many factors: social, material, health, educational etc.

The parents' level of education, their culture and pedagogical education assuredly represent important factors in achieving children's educational results. Most parents lack the knowledge of treating their children in a pedagogically correct way and also which educational methods should be applied to child education; some do not understand a child's psychological and physical development as well as certain phases of its development and therefore don't conform their educational actions towards the child; others, in a conscious or unconscious way, make mistakes in their child's upbringing possibly because of their educational and parental weaknesses: showing feelings excessively, being emotionally stingy in terms of love, showing nervousness.

A systematically conceived program involving parents began in the fifties: seminars, courses, "schools for life", parent centers, counseling clinics (pedagogical, psychological - pedagogical, pedagogical - medical, etc.). The work with parents was conducted on account of special programs, sessions and discussions involving psychologists, pedagogues, pediatricians, defectologists, lawyers, judges and others.

The aim was to make parents aware of the latest scientific discoveries in the field of child development and their upbringing, of the conditions that should provide the family with 
a positive development, to make them aware of the modern family relations, with equal relationships in society as well as in the family. All the efforts were aimed at making parents more active in the process of child education and upbringing.

A significant role was played by schools for parents which provided systematic and extensive knowledge which were directed at various aspects of family life: pedagogical, psychological, family upbringing, legal basis of a marriage and family, social protection.

Parent clubs (often parts of institutions, schools) were also very successful. They organized: lectures, music programs, discussions and other activities.

"Schools for life" were meant for young people and were organized as parts of workers' or people's universities. These schools had two levels:

- For young people age 15 - 17: the aim of the program was forming a young personality and its character, relationships between the sexes, behavior of young people;

- The second level dealt with topics relating to the preparation for marriage, the choice of a spouse, a child's position within a family.

Apart from programs for parents papers, magazines, brochures and other publications for families and parents were issued with the aim of widening the range and making necessary knowledge about children and family relationships available for a great number of parents.

While schools and parent centers, seminars, pedagogical evenings, courses primarily had an educative character, counseling clinics dealt with parents and their children when the first hardships and problems occurred.

Many of these work and assistance forms are present today, with slightly different contents of course, and some have even been developed into special social institutions. In this way marriage and family counseling centers were formed and various programs of non-formal parental education within and outside the school context were developed.

When talking about non-formal parental education, a school is mostly focused on:

- Pedagogical and psychological parental education involving psychologists, pedagogues, teachers, doctors...

- The participation of parents in various school bodies (parent council, school board, committees, teams) which can influence the educational work of a school and its teachers.

Non-formal parental education can have an influence on the quality of interaction between a family and the school context. It is interesting to approach the problem from the perspective of Bronfenbrenner's (Urie Bronfenbrenner) ecological development theory which denotes a constant personality development through continuous exchange of influences between natural coexisting ecological subsystems in a unique field of life. Proximal and distal processes appear in this framework. The center of this model is the child (Feinstein, Duckworth and Sabates, 2008, 25).

Interaction between a family and school is present on various levels (Figure 3). Hence, parents working on their education from the field of responsible parenting can certainly make better judgements about the quality of many fields which is certainly in the school's interest.

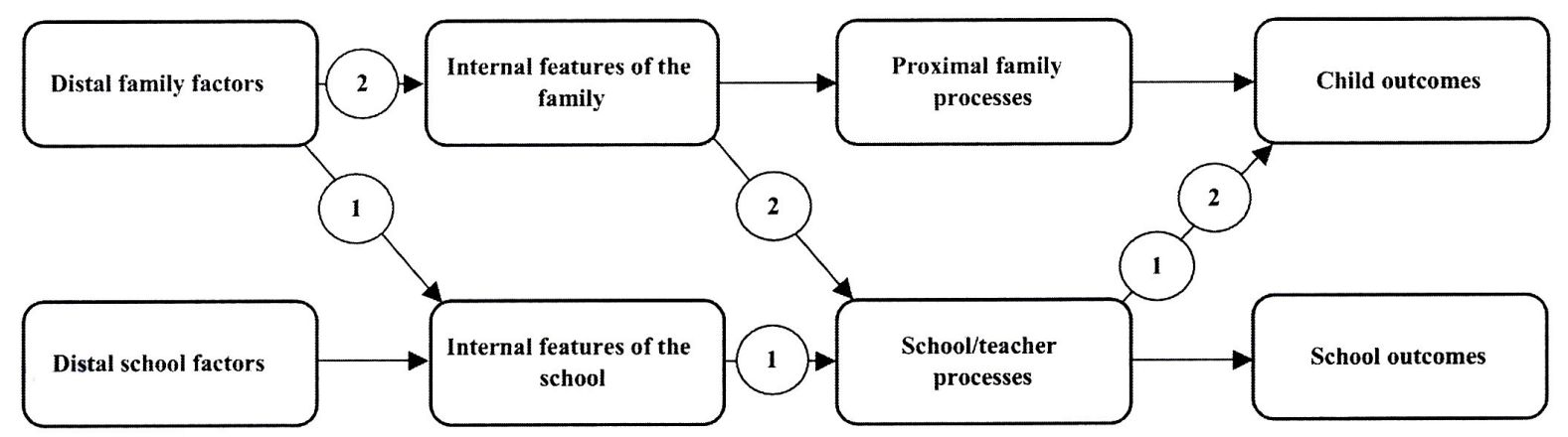

Figure 3. Conceptual model for multi-level interactions between family and school

Distal family factors influence internal characteristics of a school - they influence the objectives indirectly through the teaching process (arrow 1), but also school characteristics through another channel (resources, ethos) over attitudes and beliefs that the teachers represent (arrow 2). For example, the teachers can have higher expectancies of children whose parents are educated, or wealthy, which influences the teacher-child interaction char- 
acteristics, and yet those parents can become more proficient, skilled in the art of interaction with teachers, as well as support the school's objective (Feinstein, Duckworth and Sabates, 2008, 121-122).
In order to provide quality work on modalities of non-formal education it is necessary to bear in mind parental cognitions which are not isolated.

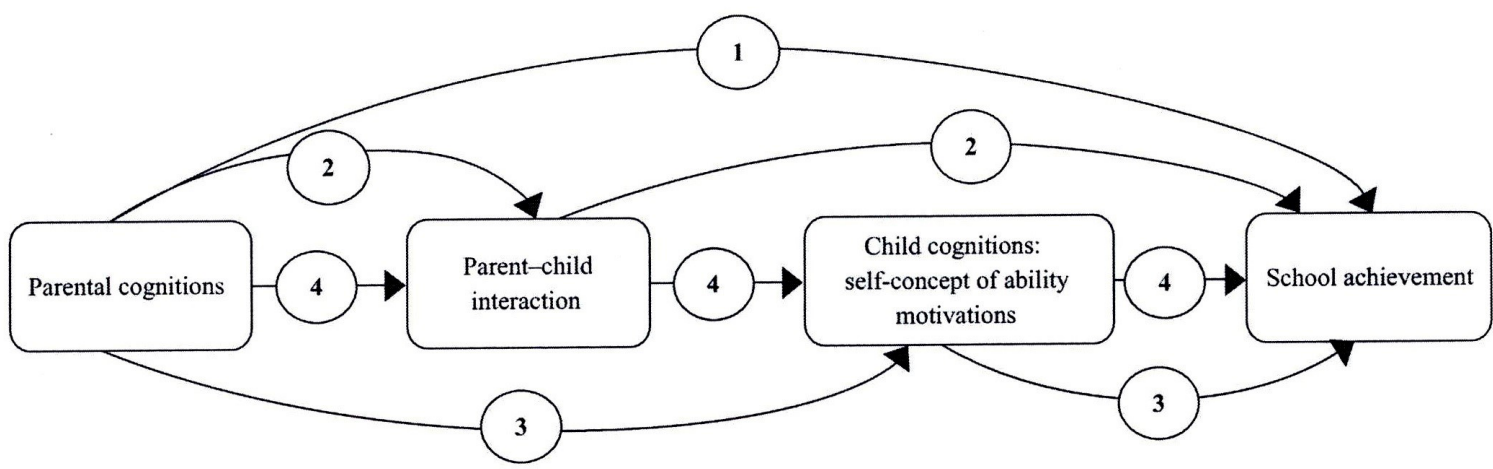

Figure 4. Some hypothesised direct and indirect influences of parental cognitions

Parental cognitions are dynamic and can have various outcomes within the parent-child interaction, child cognitions, with distal family factors and distal school factors. Possible outcomes which are not mutually exclusive in the field of family context or on a broader term, social context are displayed graphically (Figure 4) (Feinstein, Duckworth and Sabates, 2008, 78-79).

\section{MATERIALS AND METHODS}

The objective of this survey was to discover to what degree parental non-formal education is present within the function of responsible parenting. The objectives of this survey were:

- To determine the presence of certain forms of parental non-formal education;

- To examine parental expectations of non-formal education;

- To determine the level of acceptance of parental non-formal education compared to socio-demographic variables;

- To examine the predictions of parental non-formal education.

It is assumed that forms of parental non-formal education (forms which were organized by schools and those organized outside the school context) are different in terms of functions within responsible parenting. The following sub-hypotheses are posed:

h1 It is expected that the most prevalent forms of parental non-formal education would be the forms organized by schools;

h2 Parent's expectations of non-formal education will be dominant with the aim of facilitating their child's involvement in school life;

$\mathrm{h} 3 \mathrm{It}$ is expected that mothers would to a greater degree accept non-formal education as opposed to fathers, that unemployed parents would to a greater degree accept non-formal education than the employed parents and parents with the highest educational level would be most likely to accept non-formal education;

h4 It is expected that the predictors of non-formal parental education would be: gender, work status and the level of formal education.

The questionnaire research method was used in the survey. For the purpose of this research a questionnaire was constructed consisting of 13 questions which relate to the forms of non-formal education, and another questionnaire consisting of 10 questions about the parents' expectations of non-formal education. The survey was conducted during the months of March and April 2017.

The sample included 198 parents of elementary school pupils from the Bor municipality. Table 1 displays the sample structure, for the sake of viewing, according to the socio-demographic variables: gender, work status and the level of formal education. 
(IJCRSEE) International Journal of Cognitive Research in Science, Engineering and Education Vol. 5, No.1, 2017.

Table 1. Sample demographic characteristics

\begin{tabular}{lc}
\hline & $\mathbf{N}=\mathbf{1 9 8}$ \\
\hline Gender, $\mathrm{n}(\%)$ & \\
\hline male & $99(50.0 \%)$ \\
\hline female & $99(50.0 \%)$ \\
\hline Work status, $\mathrm{n}(\%)$ & \\
\hline unemployed & $34(17.2 \%)$ \\
\hline employed & $164(82.8 \%)$ \\
\hline
\end{tabular}

Level of formal education,

$\mathrm{n}(\%)$

\begin{tabular}{lc}
\hline Elementary school degree & $10(5.1 \%)$ \\
\hline High school degree & $98(49.5 \%)$ \\
\hline Associate degree & $43(21.7 \%)$ \\
\hline University degree & $41(20.7 \%)$ \\
\hline Master degree or Ph.D. & $6(3.0 \%)$ \\
\hline
\end{tabular}

The sample is completely homogenous in terms of gender. Most of the respondents are employed $(82.8 \%)$. The sample structure in terms of formal education consists of $5.1 \%$ of the respondents with an elementary school degree, $49.5 \%$ of the respondents possess a high school degree, $21.7 \%$ possess an associate degree, $20.7 \%$ possess a university degree, while only $3 \%$ possess a master degree or a Ph.D.

In the analysis of parental non-formal education, the following statistical methods were used: the arithmetic mean with the corresponding standard variation form the descriptive statistics measures, and frequencies and percentages were used for the display of qualitative variables. The differences between groups were determined by One-way variance analysis (ANOVA). The Student $t$ test was used for large independent samples.

Variables that proved as statistically important in the pre-analysis were entered into the univariate regression linear model. Those that were statistically important in this model in explaining the dependent variable were entered into the multivariate model. Therefore, for the purpose of prediction univariate and multivariate linear regressions were used.

Statistical significance was defined at the level of probability of the null hypothesis at $p \leq 0.05$. Statistical processing and analysis was done in the computer program SPSS ver. 21 (Statistical Package for the Social Sciences).

\section{RESULTS}

Table 2 displays the percentage distribution of the parents' answers to questions relating to the forms of non-formal education within the schools the parents participated in.

Table 2. The forms non-formal education within schools in which the parents participated the most, descriptive indicators

\begin{tabular}{|c|c|c|}
\hline & & $\mathbf{N}=198$ \\
\hline $\begin{array}{l}\text { Parent-teacher meeting } \\
(\%)\end{array}$ & no $(\%) /$ yes & $13(6.6 \%) / 185(93.4 \%)$ \\
\hline Lectures for parents & no $(\%) /$ yes $(\%)$ & $130(65.7 \%) / 68(34.3 \%)$ \\
\hline Planned individual counselling & no $(\%) /$ yes $(\%)$ & $150(75.8 \%) / 48(24.2 \%)$ \\
\hline Individual counseling on the parents' initiative & no $(\%) /$ yes $(\%)$ & $13166.2(\%) / 67(33.8 \%)$ \\
\hline Individual counseling on the head teacher's initiative & no $(\%) /$ yes $(\%)$ & $151(76.3 \%) / 47(23.7 \%)$ \\
\hline Activities in the parent council & no $(\%) /$ yes $(\%)$ & $174(87.9 \%) / 24(12.1 \%)$ \\
\hline Performing certain tasks at school & no $(\%) /$ yes $(\%)$ & $184(92.9 \%) / 14(7.1 \%)$ \\
\hline Written communication with the head teacher & no $(\%) /$ yes $(\%)$ & $181(91.4 \%) / 17(8.6 \%)$ \\
\hline Written inquiry & no $(\%) /$ yes $(\%)$ & $183(92.4 \%) / 15(7.6 \%)$ \\
\hline Consulting the school psychologist/pedagogue & no $(\%) /$ yes $(\%)$ & $163(82.3 \%) / 35(17.7 \%)$ \\
\hline Non-formal education score, $\quad$ minimum - maximu & minimum - maximum (mean $\pm S D)$ & $2-9(7.33 \pm 1.66)$ \\
\hline \multicolumn{2}{|c|}{$\begin{array}{l}\text { Do you educate yourself regularly on the topic of parental education on } \\
\text { family life and child upbringing? regularly }(\%) / \text { sometimes }(\%) / \text { never }(\%)\end{array}$} & $33(16.7 \%) / 124(62.6 \%) / 41(20.7 \%)$ \\
\hline \multicolumn{2}{|c|}{$\begin{array}{l}\text { Have you ever attended a counseling session for parents or talked to a } \\
\text { specialist about your child's upbringing? }\end{array}$} & $18(9.1 \%) / 51(25.8 \%) / 129(65.2 \%)$ \\
\hline \multicolumn{3}{|c|}{ regularly(\%)/ sometimes(\%)/never(\%) } \\
\hline \multirow{2}{*}{\multicolumn{2}{|c|}{$\begin{array}{l}\text { Have you ever been a student of a school for parents? } \\
\qquad \text { regularly }(\%) / \text { sometimes }(\%) / \text { never(\%) }\end{array}$}} & $20(10.1 \%) / 10(5.1 \%) / 168(84.8 \%)$ \\
\hline & & \\
\hline
\end{tabular}


The greatest percentage of parents attended parent-teacher meetings with $93.4 \%$, a notable percentage of parental attendance on lectures for parents was observed at $34.3 \%$ and individual counseling on the parents' initiative at $33.8 \%$. Next on the list were other forms of parental non-formal education which were present in a lesser degree: consulting the school pedagogue with $17.7 \%$, planned individual counseling with $24.2 \%$, individual counseling on the head teacher's initiative with $23.7 \%$, activities in the parent council with $12.1 \%$, written communication with the head teacher with $7.6 \%$ and performing certain tasks at school with $7.1 \%$.

The end score of non-formal education was calculated in accordance with the above mentioned items. The score theoretically scales between 0 and 10 because it represents the set of positive answers on questions explaining non-formal education. However, the end scores range from 2 to 9 , and the achieved average of a sample is $7.33 \pm 1.66$.

The respondents' task was to answer three additional questions about non-formal education, and the results show that $16.7 \%$ of parents educate themselves regularly on the topic of parental education on family life and child upbringing, 9.1\% attend a counseling session for parents or talk to a specialist about their child's upbringing, while $10.1 \%$ of all parents were students at a school for parents.

Table 3 displays the scores depicting the parents' expectations of non-formal education.

Table 3. Parents' expectation of non-formal education, descriptive indicators

\begin{tabular}{|c|c|c|}
\hline & & $\mathrm{N}=198$ \\
\hline To facilitate their child's involvement in school life & no $(\%) /$ yes $(\%)$ & $81(40.9 \%) / 117(59.1 \%)$ \\
\hline To appease teachers & no $(\%) /$ yes $(\%)$ & $195(98.5 \%) / \quad 3(1.5 \%)$ \\
\hline To assist the school in child upbringing & no $(\%) /$ yes $(\%)$ & $155(78.3 \%) / 43(21.7 \%)$ \\
\hline To unify their demands of the child with he views and demands of the school & no $(\%) /$ yes $(\%)$ & $122(61.6 \%) / 76(38.4 \%)$ \\
\hline $\begin{array}{l}\text { To provide the most favorable conditions for child development through par } \\
\text { ordinated actions }\end{array}$ & $\begin{array}{l}\text { rent-teacher co- } \\
\text { no (\%) / yes (\%) }\end{array}$ & $42(21.2 \%) / 156(78.8 \%)$ \\
\hline To educate themselves on the appropriate actions applicable in education & no $(\%) /$ yes $(\%)$ & $151(76.3 \%) / 47(23.7 \%)$ \\
\hline To assist the school in various tasks & no $(\%) /$ yes $(\%)$ & $178(89.9 \%) / 20(10.1 \%)$ \\
\hline Doesn't expect anything, the parent is involved pro forma & no $(\%) /$ yes $(\%)$ & $196(99.0 \%) / \quad 2(1.0 \%)$ \\
\hline Doesn't expect anything and isn't involved & no $(\%) /$ yes $(\%)$ & $197(99.5 \%) /$ \\
\hline Expects something else & no $(\%) /$ yes $(\%)$ & $198(0 \%)$ \\
\hline
\end{tabular}

The greatest percentage of parents said that their greatest expectation of non-formal education is to provide the most favorable conditions for child development through parentteacher coordinated actions $78.8 \%$, a large percentage wants to facilitate their child's involvement in school life $59.1 \%$, as well as to unify their demands of the child with he views and demands of the school $38.4 \%$. The percentage of parents who wants to educate themselves on the appropriate actions applicable in education approximates at $23.7 \%$, to assist the school in child upbringing expect $21.7 \%$ of the parents, while only $10.1 \%$ of the parents expect to assist the school in various tasks. An insignificant percentage of the parents expects: to appease teachers $1.5 \%$, doesn't expect anything, the parent is involved pro forma $1.0 \%$, doesn't expect anything and isn't involved $0.5 \%$.

We also studied whether there is a difference in degree of acceptance of non-formal education according to the socio-demographic variables. The results are displayed in Table 4. 
Table 4. Non-formal education score depending on socio-demographic variables

\begin{tabular}{|c|c|c|}
\hline & $\begin{array}{c}\text { Non-formal } \\
\text { education score }\end{array}$ & $\mathbf{p}$ \\
\hline Gender & & \multirow{4}{*}{$<0,05^{\mathrm{a}}$} \\
\hline male & $7.72 \pm 1.35$ & \\
\hline female & $6.93 \pm 1.85$ & \\
\hline Work status & & \\
\hline unemployed & $7.85 \pm 1.30$ & \multirow{3}{*}{$<0,05^{\mathrm{a}}$} \\
\hline employed & $7.22 \pm 1.71$ & \\
\hline $\begin{array}{l}\text { Level of for- } \\
\text { mal education }\end{array}$ & & \\
\hline $\begin{array}{l}\text { Elementary } \\
\text { school degree }\end{array}$ & $7.80 \pm 0.91$ & \multirow{5}{*}{$<0,001^{b}$} \\
\hline $\begin{array}{l}\text { High school } \\
\text { degree }\end{array}$ & $7.97 \pm 0.78$ & \\
\hline $\begin{array}{l}\text { Associate } \\
\text { degree }\end{array}$ & $6.41 \pm 2.29$ & \\
\hline $\begin{array}{l}\text { University } \\
\text { degree }\end{array}$ & $6.73 \pm 1.92$ & \\
\hline $\begin{array}{l}\text { Master degree } \\
\text { or Ph.D. }\end{array}$ & $6.66 \pm 1.75$ & \\
\hline
\end{tabular}

The results show that males (fathers) are more likely to accept non-formal education $(7.72 \pm 1.35)$ than females (mothers) $(6.93 \pm 1.85),(p<0.05)$. Unemployed parents have a greater score on non-formal education $(7.85 \pm 1.30)$ than employed parents (7.22 \pm 1.71$),(p<0.05)$. There is also the difference in the acceptance of non-formal education in accordance with the level of formal education $(\mathrm{p}<0.001)$. Respondents with a high school degree have the highest level of acceptance of non-formal education $(7.97 \pm 0.78)$, while the lowest interest is seen in respondents with an associate degree $(6.41 \pm 2.29)$. If we examine average percentages, we can observe that respondents with lower level degrees of formal education (elementary school and high school) have higher scores in non-formal education, i.e. display a higher level of interest towards non-formal education than those with higher levels of education.

After testing the differences, the variables that proved to be statistically important were entered at first in the universal regression model, and depending on the significance in this model, they were also entered in the multivariate regression model. Results are displayed in Table 5. significance;

aStudent's t - test; bANOVA test; $\mathrm{p}$ - statistical

Note: mean \pm standard deviation are shown in table

Table 5. Prediction of non-formal education

\begin{tabular}{|c|c|c|c|c|c|c|}
\hline \multirow{2}{*}{$\begin{array}{l}\text { Independent } \\
\text { variables }\end{array}$} & \multicolumn{3}{|c|}{$\begin{array}{c}\text { Univariate linear regression } \\
\text { analysis }\end{array}$} & \multicolumn{3}{|c|}{$\begin{array}{c}\text { Multivariate linear regression } \\
\text { analysis }\end{array}$} \\
\hline & OR $(95 \% \mathrm{CI})$ & $\mathbf{p}$ & $\begin{array}{l}\text { Adjusted } \\
\text { R Square }\end{array}$ & OR $(95 \% \mathrm{CI})$ & $\mathbf{p}$ & $\begin{array}{l}\text { Adjusted } \\
\text { R Square }\end{array}$ \\
\hline Gender & $-0.23(-1.24--0.33)$ & $<0.001$ & 0.05 & $-0.27(-1.33--0.48)$ & $<0.001$ & \multirow{3}{*}{0.18} \\
\hline Work status & $-0.14(-1.24--0.01)$ & $<0.05$ & 0.02 & $-0.07(-0.91-0.25)$ & 0.266 & \\
\hline $\begin{array}{l}\text { Level of formal } \\
\text { education }\end{array}$ & $-0.33(-0.81--0.34)$ & $<0.001$ & 0.11 & $-0.33(-0.81--0.35)$ & $<0.001$ & \\
\hline
\end{tabular}

OR-odds ratio, $\mathrm{p}$ - statistical significance;

Univariate linear regression analysis shows that statistically important predictors of the level of acceptance of non-formal education are: gender (OR: $-0.23(-1.24--0.33), \mathrm{p}<$ 0.001 ), work status (OR: $-0.14(-1.24--0.01)$, $<0.05)$ and level of formal education (OR: $-0.33(-0.81--0.34), \mathrm{p}<0.001)$. All the variables are non-formal education predictors.

After the previous analysis, we wanted to examine the results when we place all the predictors into one common model. In a multivariate model, predictors that stand out as statistically important are: gender (OR: -0.27 $(-1.33--0.48), p<0.001)$ and the level of formal education (OR: $-0.33(-0.81-\quad-0.35)$, $\mathrm{p}<0.001)$. These variables altogether explain about $18 \%$ of the dependent variable variance. Therefore, gender and the level of formal edu- 
cation influence the acceptance of non-formal education.

\section{DISCUSSIONS}

The survey was conducted on 198 respondents (the parents of eight grade pupils of an elementary school) in a completely homogenous environment in terms of gender. The focus of the survey was on: the presence of certain forms of non-formal education of parents, the parents' expectations of non-formal education, the level of acceptance of parental non-formal education in relation to both sociodemographic variables and on the parents' predictions of non-formal education.

Research results were related to certain forms of parental non-formal education, firstly those realized in schools, secondly forms of non-formal education such as self-education through reading literary works, attending parent counseling sessions or talking to a specialist about child upbringing and attending schools for parents.

Research shows that from the above mentioned forms of parental non-formal education the most dominant form is parentteacher meeting $(93.4 \%)$. This form of nonformal education is traditionally very well accepted by parents. The value of this form is reflected in the converting/receiving of formal information (about success, truancy, eventual problems etc.). Frontal or interactive work type (most frequently educational workshops) is very common for parent-teacher meetings. Parents usually feel comfortable in those situations.

Unsatisfactory results from the survey are the readiness of parents to attend lectures for parents (34.4\%) and individual counseling on the parents' initiative (33.8\%) as forms of non-formal education realized in schools. Lectures for parents allow them to gather information on various topics about child growth and development which can help influence their children's quality of life as well as their own. Therefore, results show that it is necessary for schools to get more involved on in the field of improving the quality of lectures for parents. During individual counseling, parents can acquire various information on their own initiative which are in the focus of their interests. In order for a lecture to have a functional value it is necessary for parents to follow the latest trends when it comes to topics from the field of responsible parenting, as well as the methods of their realization. It is only natural that lectures in which the parents participate will have a high efficiency level.

Parents are interested in individual counseling on the head teacher's initiative to a minor degree $(23.7 \%)$. Parents usually feel like passive receivers of information, and they usually (or mostly) see any the benefit. In these situations, parents feel uncomfortable because the most common causes for counseling are not only a bad overall grade and inappropriate behavior, but also the most common reason is the lack of communication between partners. Also, the parents are content, to a small degree, even with written communication with the head teacher (7.6\%) because they are very sensitive (they often take things personal) about the assessment of their children's achievement and behavior.

An unexpected low score was observed in the form of non-formal education related to consulting the school's psychologist or pedagogue $(17.7 \%)$. These results indicate that the parents are unaware of the significance of cooperation with the school counselors and the fact that they can provide assistance on the field of their child's education and upbringing.

Parents least correspond to the form of non-formal education in relation to work in the parent council (12.1\%) and performing certain tasks in school (7.1\%). The low score in this field can be attributed to the school's inadequately developed system of parent support. Establishing educational aims, planning and realization in cooperation with the school are relevant activities for parents because they have the opportunity to implement their educational needs which relate to responsible parenting into regular school activities.

Examination of the scores concerning the presence of certain forms of parental nonformal education that had been realized in cooperation with the school leads to the conclusion that the parents possess a positive attitude towards non-formal education which certainly influences their competences as parents. They are aware that neither school nor family alone is able to satisfy the child's educational needs.

Parents are constantly striving to become better at parenting. There are forms of non-formal education that can assist them in their endeavor: literature concerning parents' education on the topic of family life and child upbringing, counseling sessions for parents, consulting a specialist about child upbringing, attending a school for parents etc. Analysis of the research results shows that the final scores in terms of the above mentioned forms of nonformal education are quite low. 
Concerning the question of non-formal education outside schools according to the parents' answers, the highest percentage can be observed in the field of constant education on family life and child upbringing (16.7\%). The final result indicates that parents are still not entirely aware of the need to take the initiative and gather information related to child upbringing with the usage of literary works. This certainly represents a way to successful parenting.

The results show that counseling sessions for parents $(9.1 \%)$ and schools for parents $(10.1 \%)$ are forms of non-formal education with the lowest percentage. Modern society expects that parents possess competencies for responsible parenting, on the other hand it lacks investment for the development of an organized system of institutions and programs for parental education. The reason for this minimal parental involvement is the not-so-widespread system of previously mentioned forms of non-formal education.

We can conclude that from all the forms of non-formal education parents are most content with the parent-teacher meetings, and least with taking part in school tasks and also with organized forms such as counseling sessions for parents and schools for parents. The analysis of the final results indicates that the sub-hypothesis relating to the expectations that the dominant forms of non-formal parental education would be the forms organized by schools is confirmed.

Parents are mostly interested in cooperation with the school in forms which provide them with information about the overall grade or when a problem occurs which they want to settle in terms of individual contact. Schools and society in general should organize and involve parents into various forms of non-formal education.

When the parents' expectations of nonformal education are concerned, results show that parents mostly expect that through cooperated acting with the teachers/school counselors they will create the most stimulating conditions for child development and upbringing (78.8\%). Forms of cooperation with schools are the most secure way of acquiring information and educating others. These forms refer to parent-teacher meetings, individual counseling, lectures for parents, and parent involvement in certain tasks in schools. This means that schools should work on creating an environment which will encourage child development.

A large percentage of parents answered that through non-formal education they wish to facilitate their child's involvement in school's life (59.1\%). Therefore, parents are aware of the functional role of education packages which are structured in a way that enables parents to follow activities which would help them in solving various educational issues. This is possible only if a partnership between parents and the school is formed.

The result concerning the parents' expectations to unify their demands of the child with he views and demands of the school is pretty low $(38.4 \%)$. In order to take this expectation to a higher level it is necessary to develop such modalities of parental non-formal education which would affirm the parents' flexibility on one hand, and the school's empathy towards the parents' problems on the other. The refrain displayed by parents is the result of their unwillingness for cooperation, overprotective attitude towards the child and the view that the school and parents are on the opposing sides.

Another low score displayed the parents' expectations to get acquainted with the adequate procedures which should be applied to the field of child upbringing $(23.7 \%)$. Traditional education models are apparently present in today's families where the education model "as I was brought up" is dominant. However, it is important to work on the programs of parental non-formal education which are a result of following modern literary works in the fields of family and parenting, as well as to model the educational content and present it in a way that its high motivational potential is obvious.

Another low percentage of parents expect to assist the school in child upbringing through non-formal education $(21.7 \%)$. The reason for this is that parents in a greater degree think of school as an educational institution. Parents' interests, which are in the line with the school success and not educational work, are most dominant.

Based on the previous analysis, we can partially confirm our sub-hypothesis relating to the parents' expectations of non-formal education, because above the parents' expectations to facilitate the child's involvement in school life, according to the survey, there is the fact that the parents mostly expect that by cooperating with the teachers/ school counselorsthey will create the most stimulating conditions for child development and upbringing.

As a focus of this research we set the level of acceptance of parental non-formal education in comparison to socio-demograph- 
ic variables. The survey results indicate the importance of gender, work status and the level of formal education in the acceptance of non-formal education by parents. Fathers displayed a greater interest towards non-formal education despite the traditional belief that mothers are more involved in child education and upbringing. The result seems ambiguous. The result can be interpreted: firstly, as a definition of a father's role in the modern society, and secondly, as a general status of a family and society (the family still doesn't occupy the first place in society, the systems of family assistance are undeveloped, high unemployment rate, dysfunctional family patterns etc.).

Perception of the unemployed parents has a higher score on non-formal education. This result indicates that parents of the above mentioned status display a greater interest towards education and non-formal forms of involvement in various activities with the aim of creating a competent parent.

The level of acceptance of non-formal education is greater with parents of a lower level of formal education. The greatest level of acceptance was observed in parents with a high school degree as opposed to those with an associate degree or a university degree. Therefore, it is necessary to develop modalities of non-formal education which would involve parents of various educational levels. At a basic level, theoretical knowledge is of great importance, but knowledge migration as an important dimension cannot be ignored.

The analyses in comparison to sociodemographic variables are pointing to the fact that he sub-hypothesis relating to the expectation that mothers, unemployed parents and parents with the highest level of formal education to a greater extent accept non-formal education is confirmed.

All mentioned variables are a prediction of non-formal education. Therefore, the analysis in this segment indicates that the subhypothesis relating to the predictors of nonformal parental education would be gender, work status and the level of formal education is confirmed.

In a multivariate model gender and the level of formal education are considered to be statistically important predictors.

The resulting analysis stresses that is it necessary to create a participative and open environment both in schools and outside them with the aim of encouraging parental participation in various modalities of non-formal education.

\section{CONCLUSIONS}

The function of parental pedagogical education is to obtain answers from various dimensions of the parenting process. One of the main objectives of the above mentioned type of education is the transfer of knowledge which shapes the roles of parents in the sense that their components are upgraded to the level of maturation through experience in the field of competent parenting. Therefore, the parent attains great confidence in the process, he is encouraged for participation and attaining new parental experiences with a high level of responsibilities within the family as a system. Pedagogical education can be organized within all institutions with the focus on childhood assistance. In those conditions parents would have a participatory role. It should also be mentioned that acquisition of theoretical knowledge as well as comparative analysis and experience categorization of the same field of study are equally important for the development of a competent parent.

Modern society and its rapid, dynamic changes demand the development of new formal and non-formal modalities in this field of study which are not based on traditional work forms, but various work forms and interactive methods. It is necessary to offer new contexts which bear the function of complete parental involvement, contexts where they would receive basic assistance in the process of parenting. Non-formal parental education supports the concept of life-long education.

This survey leads to the conclusion that organizing efficient forms of parental nonformal education (first of all those realized in schools, secondly, other forms of non-formal education such as following scientific publications, attending counseling sessions for parents, or possible conversations with a specialist about child upbringing and attending schools for parents) is possible only when the modality possesses: a stable organizational and content structure, continuous planning, monitoring and quality control from multidisciplinary professional teams, as well as instruction materials (texts, audio and video cassettes/CDs, guides etc.) which serve not only the parents' educational needs but also their expectations. Therefore, models of non-formal education should be structured in the way that enables parents to follow the activities that could help them in resolving some issues within the family system. An additional characteristic of various forms of this type of education is in the fact that they provide opportunities for self-re- 
alization of parental competencies for responsible parenting. Teachers engaged in various forms of parental non-formal education have to be competent individuals who would, above all, understand parents/students, organize activities with se-quences of experience transfers and provide the opportunity for parents to understand and apply their newly acquired knowledge through practical activities. The key feature of parental non-formal education is that: parents/students are involved out of their own free will, it possesses a very high motivational potential, and there are often no restriction elements when it comes to age, previous educational level and experiences (the only thing necessary is that there exist realistic possibilities for monitoring the program). This implies that such a parental role in nonformal education enables their expectations of non-formal education to get even higher. At the same time this is predictive of a high level of acceptance of parental non-formal education in comparison to socio-demographic variables (gender, work status and the level of formal education).

The analysis of the results obtained in this research suggest that the main hypothesis that forms of non-formal parental education (forms which were organized by schools and those organized outside the school context) are different in terms of functions within responsible parenting is confirmed.

Formal and non-formal parental education shouldn't have the status of opposing systems. It is important to understand nonformal parental education as a complement of formal education. Therefore, non-formal education presents a new opportunity for parents to master the contents that were not available to them, that were insufficient or yet insufficiently clear within the fields of formal education.

\section{ACKNOWLEDGEMENTS}

We would like to express our gratitude to all the parents who participated in the survey realizing the significance and importance of the issue and who have also contributed to the collection of empirical data. Our sincerest gratitude goes to student councilors and head teachers of the elementary school pupils who helped with the organization of this research.

\section{REFERENCES}

Feinstein, L., Duckworth, K., \& Sabates, R. (2008). Education and the family: Passing success across the generations. Routledge. https://goo. $\mathrm{gl} / \mathrm{vob} 5 \mathrm{cW}$

Janssen, C. (2005). Il sostegno educativo domiciliare. Presupposti metodologici e strategie d'intervento. Pedagogika, 3, 8-11.

Lomov, B.F. (1979). The category of communication and activity in psychology, Questions of Philosophy. 8, 34-47.

Milani, P. (2002). Vecchi e nuovi percorsi per la pedagogia della famiglia. Studium Educationis, 1, 4-30.

Pati, L. (1999). Pedagogia familiare e denatalità. Per il ricupero educativo della società fraterna. La scuola. https://publicatt.unicatt.it/handle/10807/38168\#.WTPhN2iGO00

Pourtois, J. P., Forgione, A., \& Desmet, H. (1989). Formation des parents: Axes et instruments de changement. Les thé-matiques en éducation familiale, 263-278.

Protasevich, A.V. (2011). Non-formal education in the structure of continuous education throughout life Protasevich, A. V., \& Roitblat, O.V, Regional Education of the $21^{\text {st }}$ Century: Problems and Perspectives, 2, 75-76.

Simeone, D. (2012). L'esperienza delle scuole per genitori. LA VITA BUONA, 123-138. https:// publicatt.unicatt.it/handle/10807/40619\#.WTPiSWiGO00

\section{Conflict of interests}

Authors declare no conflict of interest. 